\title{
Cost-benefit Analysis of Seedling Production on Floating Beds in a Few Selected Areas of Bangladesh
}

\author{
Mohammod Akbar Kabir (Correspondence Author) \\ Dept. of Economics, University of Dhaka, Dhaka-1000, Bangladesh \\ E-mail: akbar_kabir03@yahoo.com \\ Md. Moniruzzaman \\ Bangladesh Krishi Bank, 83-85, Motijheel Commercial Area \\ Dhaka-1000, Bangladesh \\ E-mail: monir.zaman00@yahoo.com \\ Kawsar Jahan \\ Dept. of Accounting \& Information Systems, University of Dhaka \\ Dhaka-1000, Bangladesh \\ E-mail: kjshumi@yahoo.com \\ Md. Shahjahan \\ Bangladesh Livestock Research Institute, Regional Station \\ Baghabari, Shahjadpur, Sirajganj-6770, Bangladesh \\ E-mail: mdshahjahan19@yahoo.com
}

Received: May 15, 2019 Accepted: June 18, $2019 \quad$ Published: June 20, 2019

doi:10.5296/jas.v7i2.14788 URL: https://doi.org/10.5296/jas.v7i2.14788

\begin{abstract}
The aim of this study was to calculate the cost benefit analysis and economic viability of seedling production on the floating bed at Nazirpur Upazila in Pirojpur district of Bangladesh. The study area was selected purposively and 50 households (HHs) were surveyed through purposive sampling technique from a population of 80 households. From the results of those primary data, it was found that $68 \%$ farmers were engaged in seedling production as business purpose, and $30 \%$ as both own and business, 21 vegetables and spices seedlings were cultivated in the studied area. Average per square meter cost for floating seedling cultivation
\end{abstract}


found BDT (Bangladeshi taka) 281 and benefit was BDT 401. The net benefit of floating agriculture found BDT 120 and with a BCR of 1.43. Income from floating seedlings mainly utilized in winter vegetable cultivation (Kandi), mainstream agriculture, business, house development and land purchase etc. Fifty percent (50\%) of the floating farmers mentioned various constraints regarding floating seedling production such as lack of government aid, higher interest from NGOs and lack of capital. Among the surveyed respondents, $64 \%$ agreed that floating cultivation is effective to combat climate change and $76 \%$ replied as beneficial to the environment. Although floating agriculture is an indigenous age-old practice in the South-western region of Bangladesh, it can be replicated with the help of subsidy and agro-technology.

Keywords: benefit cost ratio, floating cultivation, indigenous method, net present value

\section{Introduction}

Today across the globe climate change has appeared as our misfortune (Pavel et al., 2014). There are frequent changes of weather events in low-lying coastal zones all over the world (Uyigue \& Agho, 2007). People are being confronted against the adverse effects of climate change, it is simply a matter of changes in weather patterns which is already a matter of survival; too little water or too much, not enough food to go around, risks to safety and security (Rahman \& Alam, 2003; CARE, 2011).

The economy of Bangladesh is mostly based on agriculture and vulnerable to climate change impacts (Easterling et al., 2007). Geographically Bangladesh is the most climate induced vulnerable country in the world (Dasgupta et al., 2016). In 2017, Global Climate Risk Index has ranked Bangladesh at $6^{\text {th }}$ position as the most affected country (Kreft et al., 2016) by the impacts of weather-related loss events like storms, floods and heat waves. These days, Bangladesh experiencing shorter winter season due to climatic reason which is liable for less food production. To be sustainable in food production, it is high time for Bangladesh to adapt with this situation. Besides new technology adoption, Indigenous methods can be effective in this phenomenon. The farmers of southern districts (Barisal, Pirojpur, Gopalgonj, Shatkhira etc.) of Bangladesh practicing indigenous cultivation (Haq et al., 2004), known as floating cultivation referred to "Vasoman Chash" (Haq et al, 2016) an age-old traditional practice continuing for centuries. It provides adaptation benefits through crop production during monsoon season in waterlogged areas (Rahman, 2014).

Floating cultivation, simply stated, is growing of seedlings and crops on water without soil (Haq, 2009) which is one of the forms of Hydroponics. Both natural and artificial floating beds are used (John et al., 2009) for agriculture in many tropical wetlands of the world. Water hyacinth is the major ingredient of soilless cultivation (Irfanullah et al., 2008) to make floating bed locally known as dhap. Farmers make the bed as their desired size and shape. After construction of bed saplings are put on the bed. Two widely used methods such as ball (guti, tema) method and spreading seed directly on the bed are used for seed germination (SATNET, 2014).

Seedling production is very much attractive and profitable than vegetable production. The 


\section{Macrothink

farmers of few sub-districts of Pirojpur and Barisal produce seedling as the commercial purpose. Nesarabad, in the North-eastern part of Pirojpur District, is one of the main suppliers of seedling (Islam \& Atkins, 2007) all over the country. In each season, farmer can sell three to four cycle of seedling from one bed. The floating seedlings may help to eradicate poverty by increasing food security and creating women empowerment (Pavel et. al., 2014). The present research attempts to calculate cost-benefit analysis and viability of floating seedling cultivation in the wetland areas of Bangladesh.

\section{Materials and Methods}

\subsection{Location of the Studied Areas}

The research work was performed in two villages at Nazirpur Upazila in Pirojpur District (Figure 1 and Figure 2). The Global Positioning System (GPS) coordinate values of each village are given in Table 1.

Table 1. GPS Coordinate Values of Different Villages

\begin{tabular}{c|c|c|c|c|c}
\hline District & Upazila & Union & Village & Longitude & Latitude \\
\hline Pirojpur & Nazirpur & Kalardoania & Mugarjhor & 22.8078 & 90.0351 \\
\hline & $\begin{array}{c}\text { Deaulbari } \\
\text { dobra }\end{array}$ & Manoharpur & 22.8358 & 90.0271 \\
\hline
\end{tabular}

Source: http://en.banglapedia.org/index.php?title=Nazirpur_Upazila

Nazirpur Upazila has an area of 233.63 sq. $\mathrm{km}$. The temperature ranges from maximum $29.9^{\circ} \mathrm{C}$ to minimum $19{ }^{\circ} \mathrm{C}$ and annual rainfall $1975 \mathrm{~mm}$. Nazirpur has an average literacy rate of $57.50 \%$. Ownership of agricultural land: landowner $76.10 \%$ and landless $23.90 \%$. The ecology of the two villages of Nazirpur was more or less same. Economy of Nazirpur is mostly based on farming and fishing. Most of the lands are lowland and marshy. Wetlands for fishing are available in Mugarjhor and Manoharpur villages. 


\section{Macrothink}

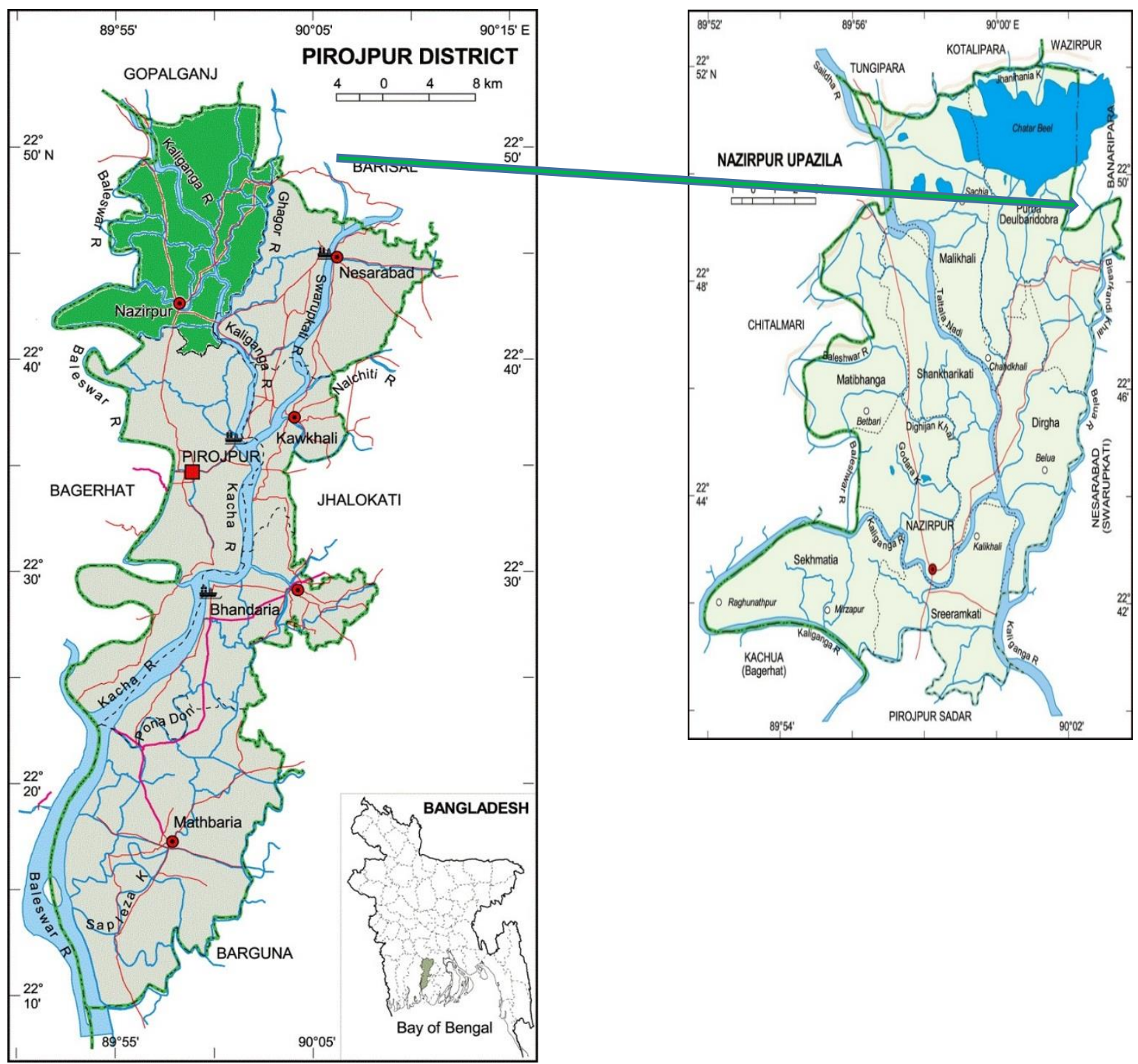

Fig 1: Map showing the Nazirpur Upazila in Pirojpur

Fig 2: Map of Nazirpur Upazila showing the working District village

Source:

Source:

http://lib.pmo.gov.bd/maps/images/pirojpur/Pirojpur-district.gif http://lib.pmo.gov.bd/maps/images/pirojpur/Nazirpur.gif

\subsection{Sampling Technique, Sample Size and Data Source}

Some areas of Barisal and Pirojpur district of Barisal Division are the only source of floating seedling agriculture. Nazirpur and Nesarabad thana of Pirojpur district are famous for floating seedling production. This study purposively selected Nazirpur Upazila as study area only because of highest number farmers of this area were practicing floating seedling in Bangladesh. Only two villages (Mugarjhor \& Manoharpur) of Nazirpur Upazila produced floating seedling and sample were selected from these villages. A population of 80 households were identified from the local floating farmer's club as sampling frame and all units of the population were planned for data collection. Data were collected from the 
members of the households who were directly involved in floating seedling production. Out of 80 households, only 50 were found at their home at the time of interview.

\subsection{Data Collection Technique}

All the data accumulated for the present study was considered as primary source because of face to face interview with the help of structured questionnaire with balanced combination of both closed and open-end questions and the same was pre-tested before finalization. The respondents were briefed about the objectives of the study before conducting the actual interview. All the interviews were conducted in Bengali and the interviews were recorded with the consent of the respondents. Besides, the researcher took field notes, made observations as well as photos of the areas. It was explained to the floating seedling farmers that the study was purely academic. Interviews were normally conducted at the respondent's house at their leisure period.

\subsection{Method of Data Processing and Analysis}

In order to find out the Cost Benefit Analysis (CBA) of the floating seedling production, the research included the financial analysis considering the timing of benefit and cost throughout the rotation period of seedlings. Discounted cost and discounted revenue measurement were used in the research.

$$
\begin{gathered}
B C R=\sum_{t=0}^{n}\left[B_{t} /(1+r)^{t}\right] /\left[C_{t} /(1+r)^{t}\right] \\
N P V=\sum_{t=0}^{n} \frac{\left(B_{t}-C_{t}\right)}{(1+r)^{t}}
\end{gathered}
$$

Where,

BCR is the benefit cost ratio, NPV is the net present value, $B_{t}$ is the benefit in each year, $C_{t}$ is the cost in each year, $t$ is the time, $t=0,1,2, \ldots \ldots, n ; n$ is the number of years, and $r$ the interest (discount) rate (assuming 0.10).

The BCR is a relative measure, which is used to compare discounted benefit per unit of discounted cost. The NPV is an absolute measure, which estimates the net worth of seedling by subtracting total revenue from total cost.

\section{Results and Discussion}

\subsection{Socioeconomic Characteristics of the Farmers}

The Socioeconomic Characteristics of the farmers involved with seedling production on floating beds are presented in Table 2. It was observed that average of age and family members of the farmers were 38.54 years and 4.98 persons, respectively. Although the 
homestead area ranged between 4-74 decimals ${ }^{1}$ with average 18.51 decimals, landless farmers were also identified regarding own cultivable land with highest 222 decimals. Most of the studied farmers cultivated on leased lands having an average 45.54 decimals. Average monthly income of floating seedling farmers obtained BDT 15160 while expenses identified was BDT 12240 per month.

The study also revealed that $94 \%$ respondents were male. The primary level education was highest (34\%) among the farmers followed by Junior School Certificate (JSC) $20 \%$ and Higher Secondary Certificate (HSC) 6\%, although a large number (30\%) was illiterate.

Table 2. Socioeconomic Characteristics of the respondents

\begin{tabular}{l|l|l|l|l}
\hline Variable & Minimum & Maximum & Mean & SD \\
\hline Age & 20 & 65 & 38.54 & 10.65 \\
\hline Family member & 2 & 9 & 4.98 & 1.55 \\
\hline Homestead land $^{\mathrm{a}}$ & 4 & 74 & 18.51 & 13.97 \\
\hline Cultivable land $^{\mathrm{a}}$ & 0 & 222 & 36.30 & 43.63 \\
\hline Lease (rent) land $^{\mathrm{a}}$ & 15 & 148 & 45.54 & 27.14 \\
\hline Monthly income $^{\text {Monthly expenses }}$ & 10000 & 30000 & 15160.00 & 3131.86 \\
\hline $\begin{array}{l}\text { Farming experience } \\
\text { (years) }\end{array}$ & 8000 & 25000 & 12240.00 & 4186.26 \\
\hline Sex Female & 50 & 23.10 & 11.79 \\
$\quad$ Male & $6 \%$ & & & \\
\hline $\begin{array}{l}\text { Education Level } \\
\text { Illiterate }\end{array}$ & $94 \%$ & & & \\
$\quad \begin{array}{l}\text { Primary } \\
\text { JSC }\end{array}$ & $30 \%$ & & & \\
$\begin{array}{l}\text { SSC } \\
\text { HSC } \\
\text { Degree and Higher }\end{array}$ & $34 \%$ & & & \\
\hline
\end{tabular}

Note: Income and expenses are measured in Bangladeshi Taka (BDT) and d denotes measures of land in decimal

Source: Authors' estimation

A similar study was conducted by Pavel et al. (2014) at Jamalgonj Upazila of Sunamgonj District of Bangladesh in which $23 \%$ of farmers were landless and average monthly income was about BDT 1000 to BDT 2000 including 60\% literacy level among the studied farmers.

\subsection{Attributes and Purpose of Seedling Production on Floating Bed}

The attributes and purpose of seedling production on floating beds of the surveyed areas are shown in Table 3. The experience of floating seedling revealed 18.08 years with a range 2-37 years among the studied farmers. About 9 days were required to prepare a floating bed for seedling production after purchase at a cost of BDT 4000 per bed. As individual cost, about BDT 261 and BDT 249 were required for bamboo and land rent per season respectively. Cost of seed, dulali lata, tupapana, bira, lata, fertilizer, pest and labor cost per cycle recorded as

${ }^{1}$ A decimal is a unit of area in Bangladesh approximately equal to 40.46 square meter 
BDT 221.50, 376, 662, 97, 137, 48, 240 and 120 respectively. However, annual net income from seedling production observed 69849 while total cost and income identified, respectively were BDT 1, 58,325 and BDT 2, 28,174.

Table 3. Attributes and Purpose of Floating Seedling Agriculture

\begin{tabular}{l|l|l|l|l}
\hline Variables & Min & Max & Mean & SD \\
\hline Floating seedling production experience (years) & 2 & 37 & 18.08 & 8.46 \\
Bed preparing time (Days) & 5 & 14 & 8.68 & 2.25 \\
Number of bed & 4 & 30 & 12.54 & 7.06 \\
Number of cycle & 3 & 6 & 4.20 & 0.756 \\
\hline Cost of Each bed per season & 4000 & 4000 & 4000 & 0 \\
Cost of Bamboo per bed per season & 200 & 320 & 260.90 & 33.92 \\
Land rent per bed per season & 170 & 334 & 248.68 & 35.59 \\
Cost of Seed per bed per cycle & 175 & 275 & 221.50 & 24.35 \\
Cost of Dulali lata per bed per cycle & 300 & 400 & 375.90 & 22.85 \\
Cost of Topapana per bed per cycle & 580 & 700 & 661.80 & 39.56 \\
Cost of Bira cost per bed per cycle & 0 & 150 & 96.80 & 61.29 \\
Cost of Lata cost per bed per cycle & 0 & 175 & 137.20 & 43.10 \\
Cost of Fertilizer per bed per cycle & 40 & 70 & 48.00 & 5.98 \\
Cost of Pest per bed per cycle & 200 & 350 & 240.20 & 23.26 \\
Cost of Labor per bed per cycle & 0 & 550 & 120.44 & 183.87 \\
\hline Annual Total cost per farmer & $48 \%$ & 378390 & 158325.36 & 93097.60 \\
Annual Total income per farmer & $50 \%$ & & & 134294.44 \\
Annual Net income per farmer & 52000 & 612000 & 228174.04 & \\
\hline Purpose of Floating Seedling Production & 5908 & 233610 & 69848.68 & 50319.42 \\
\hline Business & & & \\
Own \& Business & & & \\
\hline
\end{tabular}

Note: All costs and incomes are measured in Bangladeshi Taka (BDT)

Source: Authors' estimation

The average size of 44 sq. $\mathrm{m}$ bed was purchased at BDT 4000, seedling preparation cost per square meter was about BDT 287 and BDT 127 net income per square meter was realized. About BDT 115 cost per square meter bed was found in the study of Haq (2009) but the net return was much higher (BDT 261) than the present study. However, Hossain (2014) estimated approximately similar net return per square meter about BDT 95 and Irfanullah et al. (2005) estimated BDT 54 per square meter net income, which was lower than the present study result.

It was observed that $68 \%$ of farmers did seedling production as business purpose, and $30 \%$ as both own and business. There were 21 vegetables and spices seedlings types that were 
cultivated among the surveyed farmers and the highest number of seedlings were Bottle gourd (19.11\%) followed by Papaya (13.82\%) and Chili (12.60\%).

The findings of IUCN (2009) agreed with the present study for total number of types of seedling produced and noted that 31 seedlings of various vegetables and spices types in four districts of Bangladesh. In other studies, Pavel et al. (2014) found 17 types of seedling production on floating.

\subsection{Investment Source of Seedling Production and Source of Seeds}

The findings revealed that $32 \%$ of farmers did seedling cultivation solely from own source of money while $26 \%$ got the help from NGOs (Figure 3). During floating cultivation on beds about $50 \%$ of farmers used their own saved seeds and $26 \%$ purchased from the market (Figure 4).

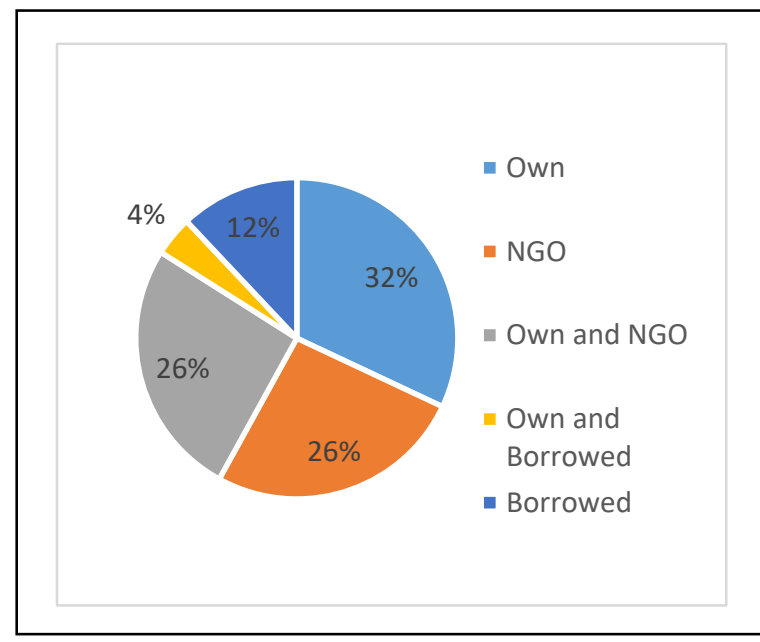

Figure 3: Source of Investment

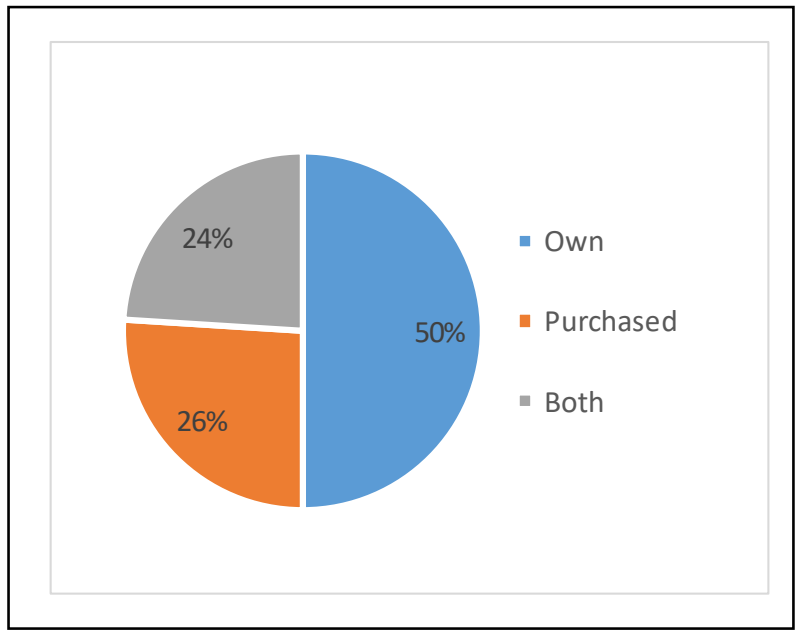

Figure 4: Source of Seeds

Source: Authors' compilation

\subsection{Cost-benefit Analysis of Seedling Production on Floating Bed}

Per bed (44 square meter) half-year (June-November) income, cost and net present revenue (NPR) of 50 floating farmers from seedling production are shown in Table 4. The highest revenue, cost and net present revenue (NPR) were BDT 20934.30, 15620.5 and 10753.7 respectively. The average values of those variables were BDT $17611.75,12369.37$ and 5242.38 respectively including a benefit-cost ratio (BCR) of 1.43 . If the BCR value is less than one $(<1)$, then a project is impossible. No farmer was found to have a BCR value less than one $(<1)$. NPR calculated considering discount rate 0.10. From CBA result, each farmer's average annual income from floating seedling production was found to be BDT 65739.45 . 
Table 4. Comparison of Revenue, Cost and NPR from Floating Seedling Production in Different Households

\begin{tabular}{llll|llll}
\hline No & Revenue & Cost & NPR & No & Revenue & Cost & NPR \\
\hline 01 & 20934.32 & 12093.31 & 8841.00 & 26 & 20562.83 & 12530.20 & 8032.62 \\
02 & 16620.88 & 13407.86 & 3213.01 & 27 & 16268.93 & 13344.54 & 2924.39 \\
03 & 14586.70 & 13312.60 & 1274.10 & 28 & 12984.40 & 9539.87 & 3444.52 \\
04 & 21892.28 & 12552.24 & 9340.04 & 29 & 12585.70 & 11393.70 & 1192.00 \\
05 & 19025.32 & 12346.14 & 6679.17 & 30 & 12862.30 & 10089.29 & 2773.01 \\
06 & 15987.99 & 12117.84 & 3870.15 & 31 & 17666.51 & 13838.75 & 3827.75 \\
07 & 15433.95 & 9996.70 & 5437.25 & 32 & 19047.19 & 11967.15 & 7080.04 \\
08 & 16964.65 & 13826.73 & 3137.91 & 33 & 16763.61 & 12096.74 & 4666.86 \\
09 & 17462.84 & 14980.21 & 2482.63 & 34 & 19770.90 & 13237.64 & 6533.26 \\
10 & 18918.77 & 13989.28 & 4929.49 & 35 & 17791.09 & 11503.66 & 6287.43 \\
11 & 18164.90 & 11881.88 & 6283.02 & 36 & 12989.18 & 10864.08 & 2125.10 \\
12 & 15322.17 & 11804.09 & 3518.08 & 37 & 19770.90 & 12464.60 & 7306.30 \\
13 & 19058.73 & 11116.58 & 7942.15 & 38 & 20024.96 & 11576.39 & 8448.56 \\
14 & 13617.91 & 12172.27 & 1445.64 & 39 & 19298.49 & 15620.46 & 3678.03 \\
15 & 17451.26 & 12187.84 & 5263.42 & 40 & 15569.90 & 9880.98 & 5688.92 \\
16 & 24766.46 & 15274.40 & 9492.06 & 41 & 18637.00 & 13650.66 & 4986.35 \\
17 & 21805.08 & 11051.41 & 10753.67 & 42 & 14703.87 & 9911.47 & 4792.40 \\
18 & 15858.24 & 11876.62 & 3981.62 & 43 & 15829.41 & 12268.80 & 3560.60 \\
19 & 20781.05 & 12703.24 & 8077.81 & 44 & 16027.64 & 12402.86 & 3624.78 \\
20 & 23653.27 & 13146.95 & 10506.32 & 45 & 16396.91 & 13993.79 & 2403.12 \\
21 & 13036.76 & 10049.02 & 2987.74 & 46 & 18663.35 & 14904.17 & 3759.19 \\
22 & 21566.62 & 15169.30 & 6397.32 & 47 & 19390.29 & 12042.21 & 7348.08 \\
23 & 17627.17 & 10455.70 & 7171.48 & 48 & 19002.48 & 12913.88 & 6088.60 \\
24 & 14278.18 & 11639.66 & 2638.52 & 49 & 20641.66 & 13323.97 & 7317.70 \\
25 & 14595.36 & 12479.23 & 2116.13 & 50 & 17927.02 & 11477.60 & 6449.43 \\
\hline Ant & 14961.75 & & & &
\end{tabular}

Annual average revenue per bed : 17611.75

Annual average cost per bed : 12369.37

Annual average net present revenue per bed (NPR) : 5242.38

Annual net revenue (NR) of 50HHs : Number of bed x NPR $=627 \times 5242.38=3286972.26$

Annual net revenue (NR) per $\mathrm{HH}: 65739.45$

Benefit cost ratio (BCR): 1.43

Note: All values of Revenue, Cost, NPR and NR are measured in Bangladeshi Taka (BDT) and valid only per bed in 0.5 years.

Source: Authors' estimation

From the study of Pavel et al. (2014), it was noted that in a period of 0.26 year depending on bed size NPR varied from BDT 6146 to BDT 127 followed by highest revenue of TK 9275 and lowest revenue of BDT 1050 with an average BCR of 2.68. A BCR of 3.17-3.9 found from seedling production in the research of Irfanullah et al. (2005) at Nanikhir village of Gopalgonj district which was about four times higher than floating vegetable cultivation. The study of Hoque et al. (2016) revealed that BCR ranged from 1.27 to 3.44 with an average 1.75. They also reported that traditional Aman rice give only 2-2.5 ton/ha yield where BCR is 
1.20 where by introducing floating agriculture gives a BCR of 1.5. Finding of the above discussion indicates that BCR declining over time. Increasing livelihood expenditure and input cost of floating seedling agriculture over time may responsible to the reduced BCR.

\section{Conclusion and Recommendations}

The study was aimed at revealing the BCR of seedling production on the basis of economic profitability and climate change adaptation. Findings revealed that majority of farmers who practiced floating agriculture met their demand of seeds from their own source, which indicate that seedling farmers are capable of producing enough to meet their need. Findings also indicate that each respondent received average annual net benefit about BDT 65739 from floating seedling production. Benefit-Cost ratio (BCR) was 1.43 which means if a farmer invested BDT 1.00 for floating seedling production then he will get net return BDT 0.43. Although the study found BCR in declining pattern over time but it might be concluded that floating agriculture could be profitable for the farmers. This BCR is significant to the floating seedling farmer as most of the farmer (68\%) did seedling production for business purpose. So, it can be decided that floating seedling is identified as a profitable practice as well as effective to combat the effect of climate change of Bangladesh.

In addition, it is a profitable and effective way to solve the scarcity of cultivable land by increasing floating agriculture are in wetlands of Bangladesh. Since Bangladesh is one of the most climate change affected countries, floating agriculture could be one viable option to combat with the effect of climate change on agriculture. Thus an integration of floating cultivation is needed with Governments mainstream agriculture planning process. Floating seedling production is confined only in some areas of Pirojpur and Barisal districts. So initiatives are needed to introduce floating seedling production in other districts of wetlands of Bangladesh. Besides, Government should implement a credit policy to provide unconditional credit with low interest rate for rural poor to expanding floating agriculture. Finally, development of an effective market system may encourage the replication of floating agriculture in Bangladesh.

\section{References}

CARE (2011). Understanding Vulnerability to Climate Change. Retrieve from https://www.google.com/url?sa=t\&rct=j\&q=\&esrc=s\&source=web\&cd=1\&cad=rja\&uact=8 \&ved=0ahUKEwjtttay253WAhVFMY 8 KHXbxDOMQFggsMAA\&url=http $\% 3 \mathrm{~A} \% 2 \mathrm{~F} \% 2 \mathrm{Fw}$ ww.careclimatechange.org\%2Ffiles\%2Fadaptation\%2FCARE_Understanding_Vulnerability. pdf\&usg=AFQjCNGm7Ew0bXVzdGVYopNQZlmixE63vg

Dasgupta, S., Huq, M., \& Wheeler, D. (2016). Drinking water salinity and infant mortality in coastal Bangladesh. Water Economics and Policy, 2(1), 1650003.

https://doi.org/10.1142/S2382624X1650003X

Easterling, W. E., Aggarwal, P. K., Batima, P., Brander, K. M., Erda, L., Howden, S. M., \& Tubiello, F. N. (2007). Food, fibre and forest products. Climate change, 273-313.

Haq, A. H. M. R. (2009). Some thoughts on soilless agriculture in Bangladesh. Wetland 
Resource Development Society, Bangladesh.

Haq, A. H. M. R., Ghosal, T. K., \& Ghosh, P. (2004). Cultivating wetlands in Bangladesh. Leisa Magazine, 20(4), 18-20. https://doi.org/10.21825/agora.v20i5.9271

Haq, M. T., Nabi, M. M. \& Kumar, D. (2016). Yield Performances of Vegetable and Spice Crops on Floating Bed. Int. J. Bus. Soc. Sci. Res. 4(4), 286-291. Retrieve from http://www.ijbssr.com/currentissueview/140131593

Hoque, M. Z., Haque, M. E., Afrad, M. S. I., \& Islam, M. N. (2106). Effectiveness of Floating Agriculture for Adapting Climate Change in Southern Bangladesh. International Journal of Economic Theory and Application. 2016a, 3(1), 14-25.

Hossain, M. A. (2014). Floating cultivation: An indigenous technology for adapting to water logging situation towards sustainable livelihood security in the low lying areas of Bangladesh. J. Biosci. Agric. Res, 1, 54-58. https://doi.org/10.18801/jbar.010114.07

Irfanullah, H. M., Adrika, A., Ghani, A., Khan, Z. A., \& Rashid, M. A. (2008). Introduction of floating gardening in the north-eastern wetlands of Bangladesh for nutritional security and sustainable livelihood. Renewable agriculture and food systems, 23(2), 89-96. https://doi.org/10.1017/S1742170507002074

Irfanullah, H. M., Nishat, A., \& Ahmed, R. (2005). Baira: The Floating Gardens for Sustainable Livelihood. IUCN-The World Conservation Union, Bangladesh Country Office.

Islam, T., \& Atkins, P. (2007). Indigenous floating cultivation: a sustainable agricultural practice in the wetlands of Bangladesh. Development in Practice, 17(1), 130-136. https://doi.org/10.1080/09614520601092733

IUCN. (2009). 2nd Phase Final Report (April 2008-June 2009): Organizing Resource Generation and Nutritional Support (ORGANS). IUCN Bangladesh Country Office, Dhaka, Bangladesh, 33.

John, C. M., Sylas, V. P., Paul, J., \& Unni, K. S. (2009). Floating islands in a tropical wetland of peninsular India. Wetlands ecology and management, 17(6), 641-653. https://doi.org/10.1007/s11273-009-9140-z

Kreft, S., Eckstein, D., \& Melchior, I. (2016). Global Climate Risk Index 2017: Who Suffers Most From Extreme Weather Events? Weather-related Loss Events in 2015 and 1996 to 2015. Germanwatch Nord-Süd Initiative eV.

Pavel, M. A. A., Chowdhury, M. A., \& Mamun, M. A. A. (2014). Economic evaluation of floating gardening as a means of adapting to climate change in Bangladesh. International Journal of Environmental 261-269. https://doi.org/10.1080/00207233.2014.911406

Rahman, A., \& Alam, M. (2003). Mainstreaming adaptation to climate change in least developed countries (LDC). Bangladesh Country Case Study.

Rahman, M. (2014). Framing ecosystem-based adaptation to climate change: Applicability in 
the coast of Bangladesh. IUCN.

SATNET, Asia (2014). Floating Vegetable Garden. Retrieve from http://www.satnetasia.org/sites/default/files/SATNET-FS09-Floating\%20Garden.pdf.

Uyigue, E., \& Agho, M. (2007). Coping with climate change and environmental degradation in the Niger Delta of southern Nigeria. Community Research and Development Centre Nigeria (CREDC), 24-27.

\section{Copyright Disclaimer}

Copyright for this article is retained by the author(s), with first publication rights granted to the journal.

This is an open-access article distributed under the terms and conditions of the Creative Commons Attribution license (http://creativecommons.org/licenses/by/4.0/). 